\title{
Inorganic Materials Biotechnology: A New Industrial Measurement Challenge
}

\section{G. J. Olson and F. E. Brinckman \\ National Bureau of Standards Gaithersburg, MD 20899}

\begin{abstract}
Biotechnological processing of inorganic, heavy elements has only begun to emerge as we start to understand microbial strategies and mechanisms of heavy element transformations. Chemical speciation of key, diagnostic intermediates and products of bioprocessing in gas, liquid, and cellular phases, and on surfaces, is required to understand and optimize important reactions. Recent discoveries of microorganisms in metalenriched thermal environments, and further investigations into production of exocellular metal transforming metabo-
\end{abstract}

lites, offer exciting prospects for development of new technologies for strategic and precious materials recovery and processing.

Key words: biotechnology; chemical speciation; chromatography; elementspecific imaging; epifluorescence microscopy; inorganic materials; metallophilic bacteria; metals bioaccumulation; ore bioprocessing; organometals; strategic metals; thermophilic leaching.

Accepted: December 5, 1985

\section{Introduction}

\subsection{Inorganic Materials Biotechnology-Its Roots} and Potential

Among the oldest of man's technologies, biotechnology has lately captured scientific, commercial, and public attention for the wide scope of organic materials such as pharmaceuticals, foodstuffs, or commodity chemicals, and improved energy economies, it presages. Basically, biotechnology "... involves the use of living or. ganisms to make commercial products and includes three major areas of research effort: recombinant DNA methodology, monoclonal antibody techniques, and bioprocessing ..." $[1]^{1}$. The recent

\begin{abstract}
About the Authors: G. J. Olson and F. E. Brinckman are with the Ceramics Division of NBS' Institute for Materials Science and Engineering. The work they describe was supported in part by the Office of Naval Research.
\end{abstract}

\footnotetext{
${ }^{1}$ Figures in brackets indicate literature references.
}

challenges and opportunities perceived for biotechnology depend upon a clear and reliable measurement base at the level of molecular biology, and hence increasingly must involve novel contributions from many chemical disciplines as well.

Not so familiar to casual onlookers and non-specialists is the fact that biotechnology deals with or more than organic materials comprised of a few light elements such as carbon, hydrogen, oxygen, nitrogen, sulfur and phosphorus; it deals with the majority of the remaining 90-odd elements that also influence our biosphere. However, inorganic materials bioprocessing is receiving attention from many industries where microorganisms are increasingly perceived as potential low-energy routes to recovering metals from ores, upgrading of ores and fossil fuels prior to conventional processing and combustion, and toxic and/or precious metal precipitation and recovery in waste streams. The po- 
tential of this biotechnology was addressed by academic, government, and industrial representatives at the recent Workshop on Biotechnology for Mining, Metal-Refining and Fossil Fuel Processing Industries [2] at Rensselaer Polytechnic Institute, Troy, NY (May 28-30, 1985). It is now clear that major sectors in North American mining technologies are moving rapidly to further develop biotechnological processing, including, for example CANMET (Canada Centre for Mineral and Energy Technology) [2] and the participation of the U.S. National Laboratories investigating "leapfrog" technologies for the steel industry [3]. One such technology would be bioprocessing of iron ores for removal of impurities or waste bioprocessing.'

Investigations into the range and potential for commercial microbial transformations of heavy elements are just beginning. This paper therefore emphasizes inorganic bioprocessing, its industrial potential, and the measurements needed to characterize, monitor, and apply the inorganic reactions that microorganisms perform.

\subsection{Environmental Perspective of Inorganic Materials Biotechnology}

The lighter "organic" molecule-forming elements (C,H,O,N,S,P) make up the bulk of cell constituents and thus are essential nutrients for cells. However, many "inorganic" or heavy elements, including both metals and metalloids are essential in biological processes, often as enzyme cofactors, but in some cases as energy sources and electron acceptors in respiration [4]. Still other heavy elements are toxic and have no known metabolic function, such as $\mathrm{Hg}$ or $\mathrm{Cd}$. Organisms which detoxify (by oxidizing, reducing, complexing, alkylating) these elements are often found associated with metal ore deposits, industrial waste discharges and other special and unusual environmental sites including, geothermal springs in terrestrial volcanic locales or geothermal sea-floor vents recently reported at great ocean depths [5]. Unexpectedly rich growths of microorganisms isolated from these metal-rich regions display capacities for heavy metal transformations even at high temperatures and pressures, implying tremendous possibilities for bioprocessing.

Microbial processing of metals and metalloids also occurs in less severe environments as evidenced by the burgeoning literature describing natural biotransformations of many elements [4]. At this point, our state of knowledge is incomplete regarding the range of beneficial as well as inimical transformations of many heavy elements. From an environmental viewpoint, this issue is, and must remain, a vital $\mathrm{R} \& \mathrm{D}$ component of monitoring and regulation. For example, the public health disasters in Japan two decades ago resulting from "Minimata Disease," or methylmercury poisoning, of a general seacoast population eating contaminated fish were exacerbated by underlying chemical and bacterial transformations of industrial mercury discharges into marine sediments and subsequent transmission into food webs [6]. Nonetheless, the same basic understanding of metals biotransformations and the related measurement methodology also supports promising new ventures in "inorganic" biotechnology.

Following the Minimata disaster, work in many laboratories, including ours at NBS, showed the prevalence of environmental mobilization by biotransformations of mercury and other heavy elements in polluted sediments [6]. Recent reports show that microorganisms may possess metal-induced resistance to metals and antibiotics $[7,8]$. Several elements besides mercury have been implicated in this way, including arsenic [9], silver [10], and cadmium [11]. Hence, applications of such results growing out of environmental and health research bears equally great promise for inorganic bioprocessing designs and applications.

\subsection{Mechanisms of Metals Biotransformations}

Since extra-chromosomal components of bacteria, called plasmids, have been demonstrated to confer new enzymatic capabilities in cells for highly effective metal- and metalloid-processing [12], and these plasmids can be genetically manipulated within current biotechnology, the earlier information on environmental impacts of such elements may now find new utility in the design and application of genetically-modified bacteria capable of industrially important processes. Plasmid mediated metal transformation often serve to detoxify metals. However, some microorganisms enzymatically oxidize heavy elements such as $\mathrm{Fe}(\mathrm{II})$, Sb(III), or U(IV) as energy sources. In certain bacteria, electrons from these reduced metals are passed to various electron acceptors spanning the cytoplasmic membrane. This generates a proton motive force across the membrane which drives ADP phosphorylation to ATP [13]. Table 1 summarizes a number of reactions for those microorganisms thus far studied and offers two examples of potential energy sources, but it should be regarded in light of the vast potential for useful reactions of many other heavy elements thus far unexplored. 
Table 1. Examples of heavy elements used as energy sources by bacteria.

\begin{tabular}{|c|c|c|c|}
\hline Metal Bioprocess & $\begin{array}{c}\text { Terminal } \mathrm{e}^{-} \\
\text {Acceptor }\end{array}$ & Organism & Ref. \\
\hline $\mathrm{Fe}^{2+\rightarrow} \mathrm{Fe}^{3+}$ & $\mathrm{O}_{2}$ & T. ferrooxidans & 13 \\
\hline $\mathrm{Sb}^{3+}+\mathrm{Sb}^{5+}$ & $\mathrm{O}_{2}$ & S. senarmontii & 14 \\
\hline $\mathrm{U}^{4+} \rightarrow \mathrm{U}^{6+}$ & $\mathrm{O}_{2}$ & T. ferrooxidans & 15 \\
\hline $\mathrm{Cu}^{+} \rightarrow \mathrm{Cu}^{2+}$ & $\mathrm{O}_{2}$ & T. ferrooxidans & 16 \\
\hline \multicolumn{4}{|c|}{$\begin{array}{l}\text { Examples of reactions that potentially yield enough } \\
\text { energy for ATP synthesis, but not yet demonstrated } \\
\text { with organisms. }\end{array}$} \\
\hline $\mathrm{Co}^{2+} \rightarrow \mathrm{Co}^{3+}$ & $\mathrm{O}_{2}$ & & 17 \\
\hline $\mathrm{As}^{3+} \rightarrow \mathrm{As}^{5+}$ & $\mathrm{O}_{2}$ & & 18 \\
\hline
\end{tabular}

The paucity of knowledge of such "inorganic" biochemistry has and will remain subject to progress with measurement state of art. Reliable methods for characterization of microbial metal transforming processes are needed both for understanding mechanisms and, ultimately, for process monitoring in the commercialization of such element-transforming processes [19].

\section{Measurement Requirements and Prospects for Inorganic Materials Biotechnologies}

Though not widely described, there already exists in the United States and elsewhere industrial use or practical demonstrations of microbial processing of metal ores in situ and sequestering of heavy metals from waste streams. Table 2 provides examples in recent use along with the key metal

Table 2. Examples of commercial applications of metals bioprocessing.

\begin{tabular}{|c|c|c|c|}
\hline Application & Industry & Ietal Product & Ref. \\
\hline \multicolumn{4}{|l|}{ Ore leaching } \\
\hline $\begin{array}{l}\mathrm{Cu} \\
\mathbf{U}\end{array}$ & $\begin{array}{l}\text { Mines in W. USA } \\
\text { Mines in Canada, USA }\end{array}$ & $\begin{array}{l}\mathrm{Cu}^{2+} \\
\mathrm{U}^{6+}\end{array}$ & $\begin{array}{l}20 \\
21\end{array}$ \\
\hline \multicolumn{4}{|l|}{$\begin{array}{l}\text { Total metal } \\
\text { precipitation }\end{array}$} \\
\hline $\begin{array}{l}\mathrm{Pb}, \mathrm{Zn} \\
\mathrm{U}^{*}\end{array}$ & $\begin{array}{l}\text { Mines in Missouri or } \\
\text { Nuclear waste effluents }\end{array}$ & $\begin{array}{l}\text { oxides, sulfides } \\
\mathrm{UO}_{2}^{2+}\end{array}$ & $\begin{array}{l}22 \\
23\end{array}$ \\
\hline \multicolumn{4}{|l|}{$\begin{array}{l}\text { Precious metal } \\
\text { recovery }\end{array}$} \\
\hline $\begin{array}{l}\mathrm{Ag} * \\
\mathrm{Ag}, \mathrm{Au}^{*}\end{array}$ & $\begin{array}{l}\text { Photographic effluents } \\
\text { Pyritic gold, silver ores }\end{array}$ & $\begin{array}{l}\mathbf{A g}^{\circ} \\
\mathbf{A g}^{\circ}, \mathbf{A u}^{\circ}\end{array}$ & $\begin{array}{l}24 \\
25\end{array}$ \\
\hline
\end{tabular}

* Laboratory scale investigations for feasibility of bioprocessing. products. The translation of laboratory demonstration to cost-effective field processing will largely depend upon the reliability and sensitivity of realtime monitoring, as well as the measurement capa bility for element-specific quantitation. Where field use is already practiced, effects of potential rate limiting toxicants and means for process optimization have yet to be fully investigated. Future developments will also likely include bioprocessing of ore concentrates under controlled conditions. In such processes, container materials must withstand corrosive biogenic agents and possibly elevated temperatures and pressures.

\subsection{Process Options}

Experience in inorganic bioprocessing to date indicates [26] that three major separate or concerted routes are effective in transforming, isolating, and concentrating desired heavy elements. These are: 1) chemomechanical separation and concentration; 2) solubilization (and redox); and 3) direct cellular uptake or accumulation.

2.1.1 Surface Pretreatments Using Biomodification. Fossil fuel upgrading employing microbial cell cultures has been used to remove pyritic sulfur, that is iron sulfide constituents, from coals either by direct solubilization of the mineral component [20], or by rendering the pyrite hydrophilic through biotransformation followed by oil agglomeration [27]. The surface-modifying microorganisms are known to produce phospholipid wetting agents or surfactants [28] which enable subsequent mechanical treatments to dissemble and separate otherwise tightly bound composite matrices.

The bacterium Thiobacillus ferrooxidans has been used in preoxidation treatments of gold and silver ores [29]. These precious metals often occur finely disseminated in iron pyrites which $T$. ferrooxidans oxidizes readily. Preoxidation of such ores improves gold and silver recoveries by subsequent conventional extraction methods.

2.1.2 Mineral Solubilization by Cells and CellFree Metabolites. Pyrite $\left(\mathrm{FeS}_{2}\right)$ oxidation by $T$. ferrooxidans, catalyzed by direct enzymatic attack and by biogenic acidic ferric sulfate solutions, is accelerated by a factor of up to $10^{6}$ over the abiotic rate [30] with important industrial and environmental consequences. Microbially catalyzed pyrite oxidation is responsible for the production of acidic coal mine drainage. However, the acidic ferric sulfate solutions generated by this oxidation also solubilize metal sulfides in mining operations employing bioleaching. 
Clear evidence was recently presented showing severe corrosion of structural iron artifacts by anaerobic bacterial production of as yet unidentified metabolites transmitted in solution or in respirant atmosphere [31].

Other evidence for a number of metabolic agents, themselves either of organic or inorganic nature, suggests that microbial solubilization of minerals is naturally widespread or can be exploited in chemical plant scale. Some of the key agents released by living cells may solubilize otherwise commonly highly refractory substances such as mineral ores, ceramics, and bulk metals as summarized in table 3. However, most of the reactions reported (table 3 ) have not identified the specific molecular entities produced by cells, nor quantitated the mechanistic path of solubilization. Recent preliminary work at NBS illustrates one mechanism of mineral sulfide solubilization by the pervasive algal metabolite methyl iodide. This metabolite appears to break metal-sulfur bridges by oxidative addition at sulfur or metal centers, weakening the crystal lattice and eventually allowing the metal to dissolve.

Production of powerful biogenic solubilizing agents can cause problems in process containment. Studies on corrosion resistance of materials to these metabolites are warranted.

2.1.3 Membrane and Cytoplasmic Uptake and Selective Precipitation of Elements. As ultratrace chemical speciation methods have gained favor and applicability, evidence has grown to support novel use of molecular topology arguments as structure-activity predictors for cell uptake of several metal species, notably tin [39]. Transmission of certain chemical forms of metals and metalloids across membranes occupies much attention of toxicologists and molecular geneticists [40] but much additional research is needed to complete our understanding of superficial membrane complexation of metal and metalloid ions, their entry into cell interiors and their ultimate fate. Nonetheless, progress has been made in describing bacterial uptaketransmission of isostructural, isoelectronic, and isosteric agents, as illustrated by the arsenate-phosphate [9], divalent cations [41], organotins [42] cases. Far more difficult will be the establishment of underlying biochemical factors that control the rate and extent of precipitation and morphology of those elements and their compounds that actually agglomerate in diffuse or specific sites within living cells. The case of Aquaspirillum magnetotacticum, a widely distributed aquatic bacterium, is of special interest because of its highly efficient and selective uptake of $\mathrm{Fe}$ (III) from solution, concentration, and derivatization to pure magnetite ultramicrocrystals aligned within the cell major axis [43]. The commercial consequences of understanding the mecha. nisms involved in such biosynthesis of hyperferromagnetic ultraparticles are significant especially in view of prospects for other strategic metals compounds.

\subsection{Element-Specific Detection, Imaging, and Quantitation}

From the foregoing discussion it is evident that progress is needed in defining tell-tale chemical reactions and their rate-determining participants within the controlling biological matrices. Understanding these processes requires measurements with a high degree of element- and speciesspecificity and extremely low detection limits characteristic of living cells. These general requirements for ultratrace analysis of chemical speciation of heavy elements undergoing con-

Table 3. Examples of metal solubilization by low-molecular weight extracellular metabolites.

\begin{tabular}{|c|c|c|c|c|}
\hline Metabolite & Source Organism & Substrate & Product & Ref. \\
\hline Methyl iodide & Marine algae & $\begin{array}{l}\text { Metal sulfides } \\
\text { SnS }\end{array}$ & $\begin{array}{l}\text { Soluble metal } \\
\mathrm{CH}_{3} \mathrm{SnI}_{3}\end{array}$ & $\begin{array}{l}32 \\
33\end{array}$ \\
\hline Siderophores & Bacteria & $\mathrm{Fe}(\mathrm{OH})_{3}$ & Iron chelates & 34 \\
\hline Unidentified & Bacteria & $\mathrm{Au}$ & Soluble gold & 38 \\
\hline Unidentified & $\begin{array}{l}\mathrm{SO}_{4}^{2-} \text { reducing } \\
\text { bacteria }\end{array}$ & $\begin{array}{c}\mathrm{Fe}^{\mathrm{a}} \text {, steel } \\
\text { brass }\end{array}$ & $\begin{array}{l}\text { Soluble } \mathrm{Fe} \\
\text { Soluble } \mathrm{Cu}\end{array}$ & $\begin{array}{l}31 \\
31\end{array}$ \\
\hline Unidentified & Penicillium & $\begin{array}{l}\mathrm{Fe}^{\circ} \text {, steel } \\
\text { Chalcocite ore }\end{array}$ & $\begin{array}{l}\text { Soluble } \mathrm{Fe} \\
\text { Soluble } \mathrm{Cu}\end{array}$ & $\begin{array}{l}35 \\
36\end{array}$ \\
\hline Methylcobalamin & Bacteria & $\mathrm{Pb}, \mathrm{Sn}$ oxides & $\begin{array}{l}\text { Soluble } \mathrm{Pb} \text {, } \\
\text { methyltin }\end{array}$ & $\begin{array}{l}37 \\
37\end{array}$ \\
\hline
\end{tabular}


trolling bio-transformations have received recent review [44], but several basic points merit emphasis in addition to common features of preconcentration, molecular separation, and selective detection within meaningful time frames. Chemical speciation of important bioprocess products may be required in solution, gas phase, on surfaces, or intracellularly.

2.2.1 Element Speciation in Cellular Media. Our laboratory has developed chromatographic systems (HPLC, GC) coupled with element-selective detectors for speciation of metal-containing biogenic molecules in gas or liquid phases at ultratrace (pg-ng) levels. Volatile forms of metals have been speciated by GC-AA $[45,46]$, or by $\mathrm{GC}$ with a flame photometric detector made selective for the element of interest by different flame gas flows and optical interference filters [47]. Solvated forms of metals can be speciated using liquid chromatography coupled with atomic absorption [48] or epifluorescence microscope (using fluorescent ligands) $[49,50]$ detectors.

2.2.2 Element Speciation at Substrate or Cell Surfaces. Methods for chemical speciation on surfaces are not as well developed as for liquid or gas media. It may be possible to dissolve or extract the material of interest from cells and perform analyses described above. We were able to measure the accumulation of tributyltin species on estuarine bacteria by HPLC-GFAA analyses of methanol extracts of cells [51]. More promising is the potential for using element- and chemical species-selec. tive fluorescent ligands for imaging these molecules on cell or substrate surfaces. Recent work in our laboratories suggests that inorganic and organotin species accumulation on bacterial cells can be monitored using a fluorescent ligand, 3-hydroxyflavone with detection by epifluorescence microscopy [52] in which the microscope isequipped with a monochromator and photometer for measuring fluorescence emission intensities at appropriate wavelengths. Another surface analysis technique, Fourier transform infrared spectroscopy, is promising for study of biological reactions at surfaces. We have begun to apply FTIR to analyze biotransformation of coal leading to removal of specific undesirable functional groups [53]. Others are just beginning to study biofilms with this method [54].

2.2.3 Element Speciation Within Cells. Intracellular microbial processing products may be studied by breaking cells (sonication, pressure disruption, chemical treatments) and analyzing their contents by methods described above. Electron microscopy with $\mathrm{x}$-ray microanalysis is useful for spa- tial characterization of elements in cells. However, nondestructive methods for speciation of process intermediates or products occurring intracellularly are more difficult. Nevertheless, recent progress in nuclear magnetic resonance spectroscopy has led to the application of this nondestructive technique to real-time monitoring of cellular metabolic processes [55].

Early work in the field of small angle neutron scattering (SANS) techniques for investigating protein structure is being undertaken [56]. However, the potential for studying intracellular metabolic processes has not been investigated. A particularly attractive model system for studying the application of SANS to biological transformations of materials is Aquaspirillum magnetotacticum - a magnetotactic bacterium that intracellularly deposits pure magnetite crystals on the order of $500 \AA$ diameter [43]. We have under. taken preliminary experiments using SANS to measure magnetite particle formation rates in cells and to better understand how the cells can perform such an exact synthesis, in terms of size and purity, of these hyperferromagnetic particles.

\subsection{Chemical Speciation and Process Monitoring}

Materials bioprocessing will increasingly require monitoring of intermediates and products diagnostic of proper or optimal conditions. A better understanding of the enzymatic transformations of toxic metals by metal resistant process organisms is also needed. This includes analyzing metal speciation in solution and gas phases and bound to cell surfaces or precipitates. Many of the measurement techniques described in the previous sections may find application for such requirements. For example, the presence of toxic metals, such as $\mathrm{Hg}$, in metal ore bioleaching systems has been suspected of inhibiting the beneficial action of the process organsims. Results in our laboratory and elsewhere showed that mercuric ions at concentrations as low as $10 \mu \mathrm{g} / \mathrm{L}$ inhibit iron oxidation by Thiobacillus ferrooxidans [57]. Iron is an energy source for the organism, and is added to the growth medium at $10-40 \mathrm{~g} / \mathrm{L}$ levels. However, we have isolated a mercury-resistant strain of this organism and, using a gas chromatograph coupled with a flameless mercury atomic absorption detector, determined that the organism reduced $\mathrm{Hg}^{2+}$ to $\mathrm{Hg}^{\circ}$ which was rapidly volatilized from the growth medium [57]. Thus, it is evident that mercury resistant strains of this species can be selected for by mercury in the environment. In collaboration with molecular biologists at Washington University, we characterized 
the mechanism of reduction and found that the organism produces a heat-stable, intracellular mercuric reductase enzyme that uses reduced nicotinamide adenine dinucleotide phosphate (NADPH) as an electron donor [58]. With this information, a selectable genetic marker is now available for others to study in more detail, using recombinant DNA techniques, the genetics of this important industrial organism.

\section{Current NBS Activities in Inorganic Materials Bioprocessing}

Exciting new prospects for inorganic materials bioprocessing are presented by some of the recently discovered thermophilic bacteria (fig. 1). These include Sulfolobus [59] and other bacteria [60] discovered in hot springs and ore dumps, and the extreme thermophiles associated with volcanic activity in shallow [61] and deep [62] ocean depths where water exists in liquid form above $100^{\circ} \mathrm{C}$. These metal-enriched vent waters support novel microorganisms which potentially are applicable to metals bioprocessing since biological and chemical reactions are accelerated under increased temperature and pressure. We have recently begun a pro- ject to evaluate the bioleaching and recovery of strategic metals, in part using thermophilic microorganisms to accelerate reactions. In addition to high temperature $\left(50-100^{\circ} \mathrm{C}\right)$ studies at ambient pressures, a high pressure-temperature bioreactor will be employed to study metal bioprocess rates at pressures up to 250 atmospheres and temperatures of up to $200^{\circ} \mathrm{C}$.

Containment and process monitoring becomes difficult under the above conditions, especially when low $\mathrm{pH}$ and corrosive metabolites are involved. Conventional steels and plastics undergo deterioration under these extreme conditions [63] and alternative materials such as advanced ceramics will be required for any future industrial applications. The economics of metal processing under such conditions will be dictated by the value of the material and the enhancement or uniqueness of microbial processing compared to chemical or physical techniques.

The processing of metals using exocellular microbial metabolites is also under investigation. We found bulk metals and metal sulfides to be dissolved by methyl iodide (table 3), a common algal and fungal metabolite. Currently, we are examining processing of ores by $\mathrm{MeI}$ and other biogenic metabolites. It may be possible to generate such

THERMOPHILIC MICROORGANISMS

\author{
organisms growing at $\geq 50{ }^{\circ} \mathrm{C}$ \\ these environments usually associated with volcanic phenomena \\ but also \\ metal ore leach dumps \\ coal refuse piles \\ decaying organic matter
}

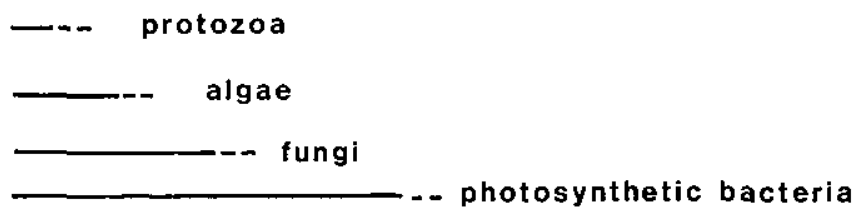

Figure 1-The relationship between maximum growth temperatures and various genera of microorganisms are compared, along with common environments supporting their growth. Newly discovered thermophilic bacteria have been shown to grow at $115^{\circ} \mathrm{C}$ under pressure [61]. Unconfirmed reports of microbial growth at $250^{\circ} \mathrm{C}$ and 200 atmospheres pressure have recently appeared [62].

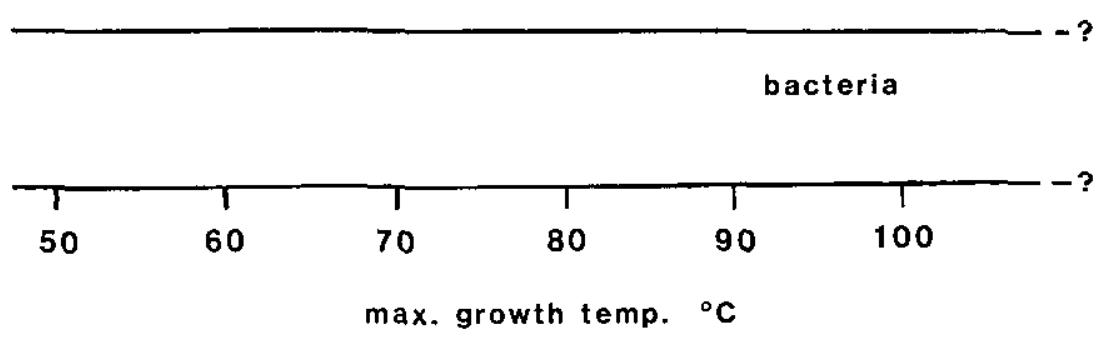


metabolites in remote bioreactors and apply the so. lutions to the material to be processed.

We are also investigating prospects for using microorganisms for synthesis of selected metal forms. For example, certain thermophilic algae precipitate nickel as the sulfide exocellularly [26], magnetotactic bacteria produce magnetite crystals from soluble iron [43], and Thiobacillus and other resistant bacteria reduce mercuric ions to elemental mercury. The use of such organisms to produce desired molecular forms of strategic or precious metals is under investigation in our laboratories.

\section{Conclusions}

Man has used biotechnology for centuries, initially for fermentations and more recently in the food, pharamaceutical, and medical fields. How- ever, we are only beginning to understand how to apply microorganisms for the recovery and processing of inorganic materials for commercial and technological applications. Our knowledge is incomplete in understanding mechanisms of microbial interactions with inorganic or heavy elements which may be transformed as energy sources, electron acceptors in respiration, or as toxic agents. Chemical speciation of such elements in aqueous, gaseous, or cellular media is essential in understanding mechanisms of biotransformations. Surface analysis or imaging is important because many biotransformations of these heavy elements involve reactions of insoluble substrates or precipitation. Newly discovered microorganisms in metal-rich thermal environments offer exciting prospects for novel and accelerated bioprocessing.

In summary, a materials cycle is presented (fig. 2) which illustrates the potential microbial role in

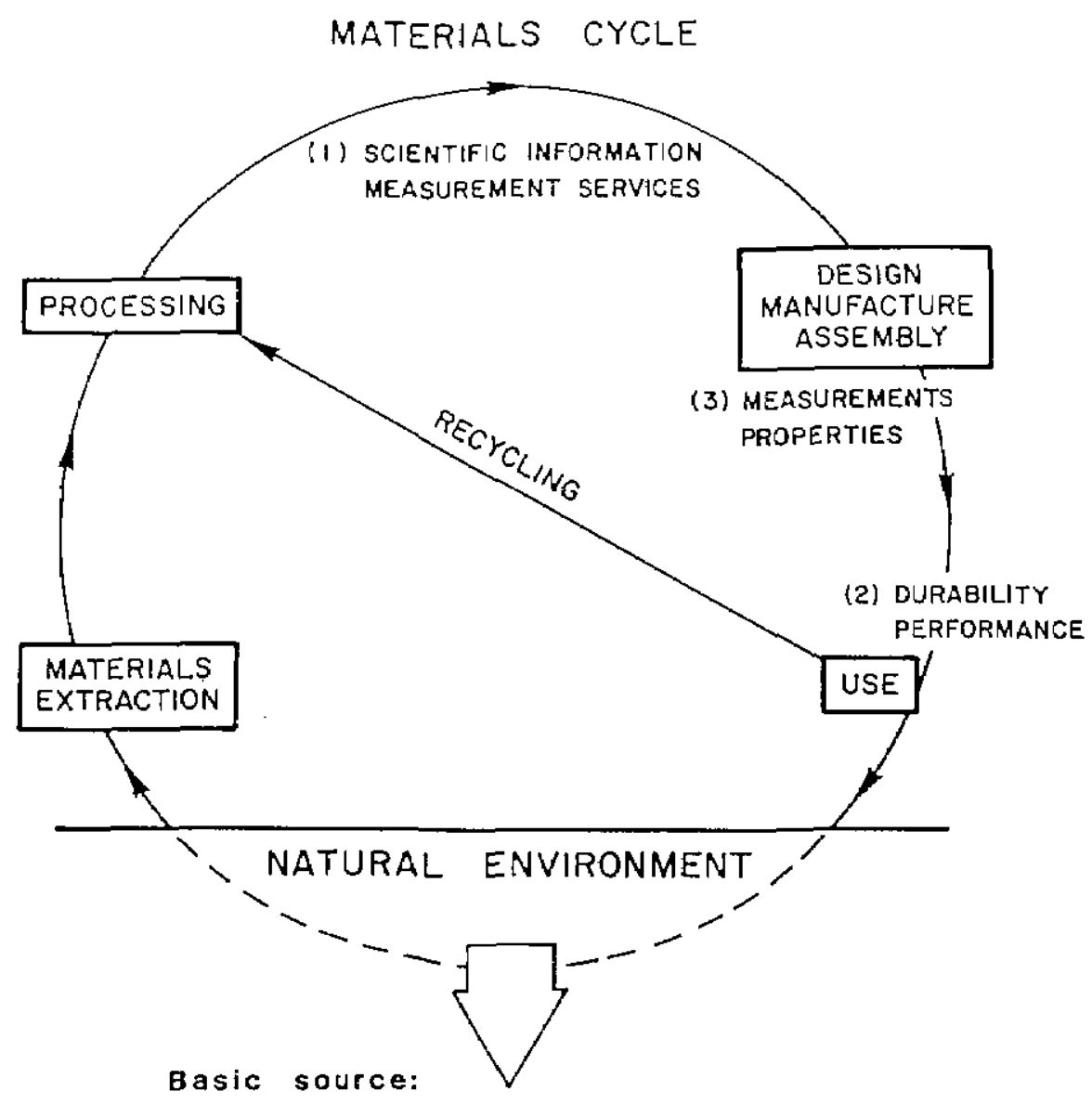

Raw/spent materials (metals, metalloids)

Genetic factors/cell mass
Figure 2-The conventional "crosscutting" features of measurements in relation to materials design, processing, use and recycling are here defined in terms of their frequent natural environmental interactions. Thereby, a coherent picture of new materials innovation and acquisition emerges in terms of biotechnological options. 
acquisition and disposition of materials (the lower portion of the circle). We have shown the importance of and potential for microorganisms in materials extraction and for recovering and recycling of heavy elements from waste or process streams. Also, future developments in processing elements into selected forms appears promising.

\section{References}

[1] Anonymous. What is biotechnology? Anal. Chem. 56, 1550A (1984).

[2] Campbell, M. C., Canadian government activities in biotechnology as it applies to the mineral industry. Paper presented at workshop for the Mining, Metal-Refining and Fossil Fuel Processing Industries, Troy, NY (May 28-30, 1985).

[3] Bowers, E. W., Steel in search of leapfrog technology, Iron Age 227, 60-63 (1984).

[4] Ehrlich, H. L., Geomicrobiology, New York: Marcel Dekker (1981).

[5] Baross, J. A.; M. D. Lilley and L. I. Gordon, Is the $\mathrm{CH}_{4}$ $\mathrm{H}_{2}$, and $\mathrm{CO}$ venting from submarine hydrothermal vent systems produced by thermophilic bacteria? Nature 298, 366-368 (1982).

[6] D'Itri, F. M., The environmental mercury problem, Cleveland: CRC Press (1972)

[7] Silver, S., Bacterial transformations of and resistances to heavy metals, in Changing Biogeochemical Cycles of Metals and Human Health, Berlin: Springer-Verlag (in press).

[8] Summers, A. O., Genetic adaptations involving heavy metals. In Current Perspectives in Microbial Ecology, M. J. Klug and C. A. Reddy, eds., Washington: American Society for Microbiology, 94-104 (1984).

[9] Silver, S., and D. Keach, Energy-dependent arsenate efflux: The mechanism of plasmid mediated resistance, Proc. Natl. Acad. Sci. USA 79, 6114-6118 (1982).

[10] MeHugh, G. L; R. C. Moellering, C. C. Hopkins, and M. N. Swartz, Salmonella typhimurium resistant to silver nitrate, chloramphenicol, and ampicillin. Lancet i: $235-239$ (1975).

[11] Tynecka, Z.; Z. Gos and J. Zajac, Energy-dependent efflux of cadmium coded by a plasmid resistance determinant in Staphylococcus aureus. J. Bacteriol. 147, 313-319 (1981).

[12] Williams, J. W, and S. Sitver, Bacterial resistance and detoxification of heavy metals. Enzyme Microb. Technol. 6, 530-537 (1984).

[13] Ingledew, J., Thiobacillus ferrooxidans: The bioenergetics of an acidophilic chemolithotroph, Biochim. Biophys. Acta 683: 89-117 (1982).

[14] Lyalikova, N. N., Oxidation of trivalent antimony up to higher oxides as a source of energy for the a new autotropic organism, Stibiobacter, gen. nov. Dokl. Akad. Nauk SSSR 205, 1228-1229 (1972).

[15] DiSpirto, A. A., and O. H. Tuovinen, Uranous ion oxidation and carbon dioxide fixation by Thiobacillus ferrooxidans, Arch. Microbiol. 133, 28-32 (1982).

[16] Nielsen, A. M., and J. V. Beck, Chalcocite oxidation and coupled carbon dioxide fixation by Thiobacillus ferrooxidans. Science 175, 1124-1126 (1972).

[17] Zajic, J. E., Microbial biogeochemistry, New York:
Academic Press, 170-171 (1969).

[18] Ehrlich, H. L. Inorganic energy sources for chenzolithotrophic and mixotrophic bacteria, Geomicrobiol. J. 1, 6583 (1978).

[19] Brinckman, F. E.; G. J. Olson and W. P. Iverson, The production and fate of volatile molecular species in the environment: metals and metalloids. In Atmospheric Chemistry, E. D. Goldberg, ed., Berlin: Springer Verlag 231-249 (1982).

[20] Brierley, C. L., Bacterial leaching. CRC Crit. Rev. Microbiol. 6, 207-262 (1978).

[21] MacGregor, R. A., Uranium dividends from bacterial leaching. Mining Engin. 54-55 (1969 March).

[22] Sterritt, R. M., and J. N. Lester, The microbiological control of mine waste pollution. Miner. Environ. 1, 45-47 (1979).

[23] Strandberg, G. W.; S. E. Shumate and J. R. Parrott, Microbial cells as biosorbents for heavy metals: Accumulation of uranium by Sacharomyces cerevisiae and Pseudomonas aeruginosa. Appl. Environ. Microbiol. 41, 237-245 (1981).

[24] Belly, R. T., and G. C. Kydd, Silver resistance in microorganisms. Dev. Ind. Microbiol. 23, 567-577 (1982).

[25] Bruynesteyn, A., Biological and chemical processing of low grade ores, in Chemistry for the Future, $H$. Grunewald, ed., Oxford: Pergamon Press, 301-304 (1983).

[26] Wood, J. M., and H. K. Wang, Microbial resistance to heavy metals. Environ. Sci. Technol. 17, 582 A-590A (1983).

[27] Kempton, A. G.; N. Moneib, R. G. L. McCready, and C. E. Capes, Removal of pyrite from coal by conditioning with Thiobccillus ferrooxidans followed by oil agglomeration. Hydrometallurgy 5, 117-125 (1980).

[28] Schaeffer, W. I., and W. W. Umbreit, Phosphotidylinositol as a wetting agent in sulfur oxidation by Thiobacilius thiooxidans. J. Bacteriol. 85, 492-493 (1962).

[29] Lawrence, R. W., and A. Brunsteyn, Biological pre-oxidation to enhance gold and silver recovery from refractory pyritic ores and concentrates. CIM Bull. 76, 107-110 (1983).

[30] Singer, P. C., and W. Stumm, Acidic mine drainage: The rate-determining step, Science 167, 1121-1123 (1970).

[31] Iverson, W. P., An overview of the anaerobic corrosion of underground metallic structures-evidence for a new mechanism, in Underground Corrosion, E. Escalante, ed., Philadelphia, PA: American Society for Testing and Materials, 33-52 (1981).

[32] Thayer, J. S.; G. J. Olson and F. E. Brinckman, Iodomethane as a potential metal mobilizing agent in nature, Environ. Sci. Technol. 18, 726-729 (I984).

[33] Manders, W. R.; G. J. Olson, F. E. Brinckman, and J. M. Bellama, A novel synthesis of methyltin triiodide with environmental implications, J. Chem. Soc. Chem. Commun. 1984: 538-540 (1984).

[34] Raymond, K. N., and C. J. Carrano, Coordination chemistry and microbial iron transport, Acc. Chem. Res. 12, 183-190 (1979).

[35] Siegel, S. M.; B. Z. Siegel and K. E. Clark, Bio-corrosion: Solubilization and accumulation of metals by fungi. Water, Air, Soil Pollut. 19, 229-236 (1983).

[36] Wenberg, G. M.; F. H. Erbisch and M. E.Volin, Leaching of copper by fungi, Soc. Mining Engin., AIME 250, 207212 (1971).

[37] Thayer, J. S., and F. E. Brinckman, The biological methylation of metals and metalloids, in Organometallic 
Chemistry, Vol. 20. F. G. A. Stone and R. West, eds., New York, NY: Academic Press, 313-356 (1982).

[38] LeRoux, N. W., Mineral attack by microbiological processes, in Microbial Aspects of Metallurgy, J. D. A. Miller, ed., New York, NY: American Elsevier, 173-182 (1970).

[39] Laughlin, R. B.; R. B. Johannesen, W. French, H. E. Guard, and F. E. Brinckman, Structure-activity relationships for organotin compounds. Environ. Toxicol. Chem. 4, 343-351 (1985).

[40] Silver, S., Mechanisms of bacterial resistances to toxic heavy metals: arsenic, antimony, silver, cadmium, and mercury, in Environmental speciation and Monitoring Needs for Trace Metal-containing Substances From Energy-related Processes. F. E. Brinckman and R. H. Fish, eds., National Bureau of Standards, Spec. Publ. 618 (1981).

[41] Silver, S., Magnesium transport in microorganisms, in M:croorganisms and Minerals, E. D. Weinberg, ed., New York: Marcel Dekker, 7-47 (1977).

[42] Wong, P. T. S.; Y. K. Chau, O. Kramar, and G. A. Bengert, Structure-toxicity relatiouships of tin compounds on algae, Can. J. Fish. 39, 483-488 (1982).

[43] Blakemore, R. P., Magnetotactic bacteria. Ann. Rev. Microbiol. 36, 217-238 (1982).

[44] Thayer, J. S., and F. E. Brinckman, The biological methylation of metals and metalloids, in Advances in Organometallic Chemistry, F. G. A. Stone and R. West, eds., New York: Academic Press, 313-356 (1982).

[45] Blair, W.; W. P. Iverson and F. E. Brinckman, Application of a gas chromatograph-atomic absorption detection system to a survey of mercury transformations by Chesapeake Bay microorganisms. Chemosphere 3, 167174 (1974).

[46] Parris, G. E.; W. R. Blair and F. E. Brinckman, Chemical and physical considerations in the use of atomic absorption detectors coupled with a gas chromatograph for determination of trace organometallic gases, Anal. Chem. 49, 378-386 (1977).

[47] Jackson, J. A.; W. R. Blair, F. E. Brinckman, and W. P. Iverson, Gas chromatographic speciation of methylstannanes in the Chesapeake Bay using purge and trap sampling with a tin-selective detector, Environ. Sci. Technol. 16, 110-119 (1982).

[48] Parks, E. J.; F. E. Brinckman and W. R. Blair, Application of a graphite furnace atomic absorption detector automatically coupled to a high-performance liquid chromatograph for speciation of metal-containing macromolecules, J. Chromatogr. 185, 563-572 (1979).

[49] Parks, E. J.; W. R. Blair, G. J. Olson, F. E. Brinckman, and $M$. C. Valeris-Price, manuscript in preparation.
[50] Parks, E. J.; W. R. Blair, G. J. Olson, F. E. Brinckman, and M. C. Valerias-Price, and J. C. Means, Ultratrace speciation of organometallic species in natural systems, using microbore and capillary techniques with an epifluorescence microscope imaging detector. Pittsburgh Conf. Anal. Chem., New Orleans, LA (March 1985),

[51] Blair, W. R.; G. J. Olson, W. P. Iverson, and F. E. Brinckman, Accumulation and fate of tri-n-butyltin cation in estuarine bacteria. Microb. Ecol. 8, 241-251 (1982).

[52] Brinckman, F. E., and G. J. Otson, Chemical principles underlying bioleaching of metals from ores and solid wastes and bioaccumulation of metals from solutions. Biotechnol. Bioengin. Symp. (in press).

[53] Olson, G. J.; F. E. Brinckman and W. P. Iverson, Bioprocessing coal with microorganisms. Proceedings report for Electric Power Research Institute (April 1985).

[54] Nichols, P. D.; J. M. Henson, J. B. Guckert, D. E. Nivens, and D. C. White, Fourier transform-infrared spectroscopic methods for microbial ecology; analysis of bacteria, bacteria-polymer mixtures and biofilms. J. Microbiol. Methods 4, 79-94 (1985).

[55] Scott, A. I., and R. L. Baxter, Applications of ${ }^{[3} \mathrm{C}$ NMR to metabolic studies. Ann. Rev. Biophys. Bioeng. 10, 151174 (1981).

[56] Stuhrmann, H. B., and A. Miller, Small angle scattering of biological structures. J. Appl. Cryst. 11, 325-345 (1978).

[57] Olson, G. J.; W. P. Iverson and F. E. Brinckman, Volatilization of mercury by Thiobacillus fernooxidans, Curr. Microbiol. 5, 115-118 (1981).

[58] Olson, G. J.; F. D. Porter, J. Rubinstein, and S. Silver, Mercuric reductase enzyme from a mercury-volatilizing strain of Thiobacillus ferrooxidans, J. Bacteriol. 151, 12301236 (1982).

[59] Brock, T. D.; K. M. Brock, R. T. Belly, and R. L. Weiss, Sulfolobus: A new genus of sulfur-oxidizing bacteria living at low $\mathrm{pH}$ and high temperature. Arch. Microbiol. 84, $54-68$ (1972).

[60] Norris, P. R.; J. A. Brierley and D. P. Kelly, Physiological characteristics of two facultatively thermophilic mineral-oxidizing bacteria. FEMS Microbiol. Lett. 7, 119-122 (1980).

[61] Stetter, K. O; H. Konig and E. Stackebrandt, Pyrodictiam: gen. nov, a new genus of submarine disc-shaped sulfur reducing archaebacteria growing optimally at $105{ }^{\circ} \mathrm{C}$, System. Appl. Microbiol. 4, 535-542 (1983).

[62] Baross, J. A., and J. W. Deming, Growth of "black smoker" bacteria at temperatures of at least $250^{\circ} \mathrm{C}$, Nature 303, 423-426 (1983).

[63] Sonnleitner, B.; S. Cometta and A. Fiechter, Equipment and growth inhibition of thermophilic bacteria, Biotechnol. Bioengin. 24, 2597-2599 (1982). 